\title{
ДИНАМІЧНЕ ОДИВНЕННЯ ЯК ЕМОЦІЙНЕ ОСВОСННЯ ЛАНДШАФТУ (НА ПРИКЛАДІ ФЕНТЕЗІ ДІАНИ ВІНН ДЖОНС)
}

\section{Євгенія Орестівна Канчура}

\author{
https://orcid.org/0000-0003-1232-1920 \\ ivha89@gmail.com \\ кандидат філологічних наук, \\ доцент кафедри теоретичної та прикладної лінгвістики \\ Державного університету «Житомирська політехніка»
}

\begin{abstract}
Анотація. У творах англійської письменниці Діани Вінн Дюонс (1934-2011), адресованих, насамперед, підліткам та юнацтву, географічні локаиії британського ландмафту виступають як оприявнений у фентезі-оповіді потенціал окремого місия, такий, що перебуває у постійній динаміиі. Подібно до культурних героїв космогонічних міфів, персонажі письменниці впорядковують простір, відновлюючи порушений баланс сил та встановлюючи гармонію духовного і матеріального. В розвідиі розглядаються художні засоби властиві метажанру фентезі, які дозволяють змоделювати трансформацію ландтафту. Так трансформаиія здійснюється через переосмислення й вербальне переформулювання ландшафту, яке втілюється у фізичній дї (ткання, розплутування нитки, гра намузичному інструменті томо). Вербалізаиія взаємин людини й землі передбачає угоду сторін, засновану на визнанні свободи волі.
\end{abstract}

Ключові слова: фентезі доби постмодернізму; доместикаиія; культурний герой; одивнення; Діана Вінн Дюконс; «Змова Мерліна».

\section{Постановка проблеми}

Однією із засадничих ознак метажанру фентезі $\epsilon$ світотворення - розбудова вторинної реальності, яка, за задумом автора, являє собою світ істинний, сакральний центр мультиверсуму. Різноманіття фентезійних світів у кожного автора має свої особливості, але, як правило, один з таких світів є першоджерелом, серцем творіння (напр., Фйонавар Г. Г. Кея, Амбер Р. Желязни, Світ Стрижню Макса Фрая), від якого тією чи іншою мірою походять всі інші світи як його варіації та віддзеркалення. Подібним чином організовані й світи англійської письменниці останньої чверті XX - початку XXI сторіччя, Діани Вінн Джонс (1934 - 2011), в романах якої Острови Благословенних (the Islands of Blest) $є$ не лише альтернативною моделлю Англії, але й першоосновою для всіх інших світів, міфопоетичним сакральним центром мультиверсума, від благополуччя якого залежать всі інші світи. Тому збереження балансу сил та гармонійного ладу центрального світу стає першочерговим завданням героїв творів, а канонічний для метажанру фентезі сюжет порятунку світу фентезійного набуває додаткове значення порятунку, тобто відновлення рівноваги, світу реального. Деміургійність метажанру фентезі передбачає не лише розроблення автором деталей нової світобудови, але й впорядку- вання та доместикацію ландшафту, який вже існує, через активну взаємодію людини й землі (один 3 домінантних мотивів літератури фентезі). Таким чином, прийоми доместикації ландшафту розглядаються в цьому дослідженні як елементи засадничої світотворчої складової поетики метажанру фентезі та, в ширшому плані, в контексті дослідження способів зображення красним письменством поєднання свідомості людини й матеріальності ландшафту 3 опертям на міфологічне підгрунтя мотиву взаємодії людини з землею.

Мета, завдання, актуальність дослідження

Посилення світових міграційних процесів, зрушення екологічного балансу, зміщення традиційно закріплених гендерних ролей викликають суттєві зміни у сталій географічній ідентичності людини кінця XX - початку XXI століть. Віддзеркалення змін у свідомості літературою фентезі як метафоричного наративу, який апелює до архітипічних першооснов свідомості, й при цьому є загальнодоступною частиною масової культури, зумовлює актуальність дослідження прийомів доместикації в літературі фентезі як прикладів емоційного освоєння ландшафту. Таким чином, розвідка має на меті аналіз прийомів доместикації, заснованих на фентезійному одивненні, яке, в творах Діани Вінн Джонс, я визначаю як динамічне. Відповідно до поставленої мети, завдан- 
нями роботи є охарактеризувати рівні одивнення, до яких вдається письменниця, розглянути види доместикаційних прийомів, які зустрічаються в творах Д. В. Джонс, виявити їхню міфологічну базу та проаналізувати роль локусу саду як доместикованого фрагменту ландшафту в квесті героїв роману «Змова Мерліна» (The Merlin Conspiracy, 2003). Окрім згаданого роману, я залучаю до роботи романи «Візок та квіддера» (Cart and Cwidder, 1975) та «Чарівні шати» (The Spellcoats,1979) 3 циклу «Квартет Дейлмарка» як такі, що містять приклади міфологічних мотивів, втілених у доместикаційних приймах. Приклади реалізації міфологічного мотиву «чоловічого дому» вибрані з романів «Мандрівний замок Хаула» (Howl's Moving Castle,1986) та «Будинок безлічі шляхів» (House of Many Ways, 2008) - цикл про чарівника Хаула. Дослідження локусу саду в «Змові Мерліна» підкріплено концепцією саду як місця контакту світів, оприявненою в романі «Вогонь та болиголов» (Fire and Hemlock, 1984). Тобто, прийоми доместикації в творчості Діани Вінн Джонс розглядаються у часовому інтервалі 1975 - 2003 (2008) pp.

Аналіз попередніх досліджень і публікацій

Творчість Діани Вінн Джонс отримала досить широку рецепцію академічного літературознавства. Слід згадати грунтовні монографії Тейї Розенберг та ін. [19], Фари Мендлесон[18], розвідки Дебори Каплан [17], Тетяни Рязанцевої [4]. Теми «англійськості» та взаємодії людини 3 ландшафтом у доробку письменниці торкалися в своїх роботах Пітер Хант [9], Фара Мендлессон [18], Чарльз Батлер [7] та Кетрін Батлер [6]. Як зазначають дослідники, поєднання фентезійного сюжету $з$ реальним англійським ландшафтом, точність його деталей - специфічна риса поетики Джонс [7, с. 31], яка вписує іiї в загальний контекст саме британського фентезі, адже за твердженням П. Ханта, є особливістю англійського конструювання фантастичного [9, с. 11]. При цьому, Ф. Мендлессон підкреслює роль емоційного й динамічного проживання ландшафту героями Джонс: «In Deep Secret and in The Merlin Conspiracy, the journey elsewhere becomes a journey through a landscape»[18, с. 81]. Проте детального аналізу та систематизації засобів взаємодії героя і ландшафту досі здійснено не було.

Виклад основного матеріалу дослідження

Доместикація ландшафту як ключовий елемент міфологічного наративу $є$ процесом перетворення незнаного, хаотичного світу на космос, світ людей. Цей процес, як зазначає О. В. Тихомирова, перед- бачає етапи номінації фрагментів ландшафту введення в історію племені, заснування поселень та королівств і визначення сакрального ядра [5, с. 77]. Названі кроки відповідають логіці встановлення контакту зі світом: акт номінації є первинним актом вербального впливу на ландшафт, закріплення його у свідомості людини; своєю чергою, заснування поселень та королівств $€$ актом фізичного приєднання людини до ландшафту, а створення сакрального ядра - вищим рівнем фіксації взаємодії людини та ландшафту, актом обгрунтування такого зв'язку на метафізичному рівні.

Зазначені процеси, актуальні для первинної розбудови фентезійного світу як віддзеркалення деміургійних міфів, в книгах Д. В. Джонс набувають нового звучання, адже застосовуються до фентезійного світу, який вже існує як даність та не потребує опису процесу первинного творіння. Тому прийом одивнення у Джонс працює на двох рівнях. Насамперед, це фентезійне одивнення, адресоване читачеві, яке відрізняється від канонічного фентезійного одивнення (зіставлення фентезійного та реального світів 3 метою оновлення погляду на останній) тим, що фантастичне, як підкреслює Ф. Мендлесон, послідовно відбувається на реальному, добре знайомому англійському читачеві грунті [18, c. 108]. Фантастичне безпосередньо прив'язується до ландшафту, вплітається в його текстуру, мов нитка у основу гобелену. Особливість сприйняття ландшафту не як окремого місця, а як потенційної можливості місця, його глибинної динамічної суті, зазначає сама Діана Вінн Джонс: «нечесно дражнити дітей зображенням місиь, яких вони ніколи не бачили < ...> але, щчо як гірський хребет Англії - то на справді хребет дракона?» [19, с. 164.]. Таким чином, одивнення погляду на реальний світ через вплетення в його текстуру фантастичного оживляє звичний ландшафт, розкриває його потенціал та наділяє його особистісними рисами.

Поряд із фенетезійним одивненням письменниця вдається до одивнення як елемента сюжету, адресованого безпосередньо персонажам твору. Таке одивнення я пропоную назвати динамічним, адже воно відбувається через активну взаємодію героя та місця дії, перетворення місця на процес, контакту як постійного руху. В цьому аспекті мотив подорожі стимулює оновлення погляду героя на ландшафт, його осмислення та встановлення контакту з ним. Ф. Мендлесон підкреслює: «Місця - не просто об'єкти, вони - дороги, namтерни, прокладені людьми. Вони не статичні, міс- 
це постійно перебудовується, і це конструювання створює сенс місця як процесу» [18, с.XXVII].

Доместикація, представлена через одивнення, передбачає фізичне оновлення місця. Види доместикації, до яких вдаються персонажі письменниці, вкорінені в найдавніших архетипових діях: ткання, розплутування нитки (прядіння) та гра на музичному інструменті, а також прибирання (функції шляху героя: XI-XIII «герої потрапляє у самотній дім» [3, с. 33-34]). Мотив прибирання як струшування тканини ландшафту присутній в романах «Змова Мерліна» та «Чарівні Шати». В романах циклу про Хаула прибирання $є$ першим суттєвим поворотом сюжету. Мотив прибирання як випробування для героїні, характерний для чарівної казки, походить, як зазначає Володимир Пропп, від інституції чоловічого дому, властивої родовому ладу [2, с. 203-206]. Дім, де ізольовано від роду мешкають парубки, $\epsilon$ територією, забороненою для жінок, проте жінка не заборонена в такому домі. Вона знаходиться там на особливому положенні, іiї функція - приготування їжі, підтримання дому в чистоті й збереження вогню. Дж. Фрезер зазначає, що це може бути дівчина або стара [цит. за 2, с. 214]. Мандрівний замок Хаула, в який потрапляє дівчина Coфi, перетворена на стару, є саме таким відокремленим від громади «чоловічим домом», що може рухатися на ногах, подібно до хатинки Баби Яги, й має виходи до різних вимірів (чоловічій дім будувався на стовпах, мав приставну драбину та декілька потаємних виходів). Софі одразу ж береться до прибирання, тим самим завойовуючи собі контакт із вогняним демоном, хранителем дому та свій законний статус «дівчини/старої в чоловічому домі» (Дж. Фрезер [цит. за 2, с. 213] підкреслює лицарське ставлення до такої гості). Дівчинці Чарліні («Будинок безлічі шляхів», 2008), яка потрапляє в дім старого чарівника, доводиться наглядати за домом, але вона категорично відмовляється від прибирання та делегує це завдання учневі чарівника Пітеру, а сама займається впорядкуванням королівської бібліотеки. Примітно, що безлад в будинку дідуся Вільяма перемагає саме Пітер, який є втіленням хаосу (він постійно плутає напрямки), а ретельна й систематична Чарліна, навпаки, тільки збільшує безлад, аж поки не здогадується поговорити з дірявою трубою водогону, тобто, вступити із простором у вербальний контакт, підкріплений чітким наміром.

Один 3 найдавніших міфологічних мотивів робота 3 ниткою, ткацтво та прядіння - втілюється у образі дівчини-ткалі Танакві («Чарівні шати»[16]), яка переносить травматичний досвід переживання війни у візерунки на тканині. Візуальна символізація досвіду (візерунки є прадавніми символами та прочитуються як розповідь) перетворює прожиті події у наратив, переформатовує реальність через сприйняття й переосмислення їх Ткалею. Танакві фіналізує ткання, вкриваючи полотном ландшафт та звільнюючи поневолену стихію. Тривалий акт символізації та зв'язування подій започатковує міфологію Дейлмарку: в авторських примітках до роману Д. В. Джонс пояснює, що персонажі роману, яких ми бачимо в образах звичайних підлітків, $\epsilon$ культурними героями цього світу та вшановуються як боги річок, гір і землі [16, с. 183]. Своєю чергою, героїня «Змови Мерліна» Родді (чиє ім'я - Аріанрод - викликає асоціації $з$ персонажкою валійської міфології, атрибутом якої $є$ веретено $з$ чарівною ниткою, - посилання на архетип Пряхи) задля відновлення рівноваги світу розплутує перемішані нитки реальності, змотує їх у клубок та вивільняє поневолену й спаплюжену землю Островів.

Творчій діалог митця й землі як приклад доместикації ландшафту втілено у образі хлопчика-барда Моріла («Візок та квіддера» [11]) і його міфологічного попередника культурного героя, барда Осфамерона (представленого підлітком у приквелі «Чарівні шати»). Моріл, як і його попередник, граючи музику, рухає гори, заступаючи шлях ворогові.

Парадигма контакту з простором як доместикації ландшафту в романі «Змова Мерліна» заснована на протиставленні динаміки й статики. Сакральний центр мультиверсуму, Острови Блаженних, це альтернативна Британія, де Англія, Шотландія та Вельс є окремими королівствами, а жива міфологічна основа прихована під нашаруваннями симулякрів сьогодення. Так, об'їзд королем території країни перетворюється із обгрунтованої дії (контакту з землею) на тягар формального обов'язку. Офіційна посада «Мерліна», коли іiі займає чарівник, що прагне лише влади й самоствердження, втрачає функції збереження магії королівства. Посаду Мерліна врівноважує Леді Управителька (Lady of Governance). Порушена рівновага сил в сакральному центрі проявляється в мотивах дощу та сухої землі, як ознак вихолощення королівської сили. Проте архетипічні сили зберігаються самою землею: міста королівства представлені як особистості, в пагорбі спить Білий Дракон, ліс приховує Лорда Хранителя, Володарка Северна зберігає чистоту землі. Місця сили, між якими мандрує королівський почет, упізнаванні, всі вони є на мапі 
Англії (напр., Уффінгтонський Білий кінь, Стоунхендж тощо) [6, с.13-15] Окрім загальновідомих місць сили, поворотними точками подорожі як проживання англійського ландшафту є сади.

Контраст руху і статики як функцій чоловічого й жіночого початків, втілений у системі персонажів роману, представлено у таблиці 1 :

Таблиця 1.

\begin{tabular}{|c|c|c|}
\hline & Чоловіки & Жінки \\
\hline $\begin{array}{l}\text { Офіційні } \\
\text { посади }\end{array}$ & Король із почтом & $\begin{array}{l}\text { Леді } \\
\text { Управителька }\end{array}$ \\
\hline $\begin{array}{l}\text { Рух / } \\
\text { Статика }\end{array}$ & $\begin{array}{l}\text { Відтворює риту- } \\
\text { ал: об'їжджає } \\
\text { королівство. } \\
\text { Дискомфорт } \\
\text { у дорозі, від- } \\
\text { сутність нор- } \\
\text { мальних умов } \\
\text { для життя та } \\
\text { розвитку. }\end{array}$ & $\begin{array}{l}\text { Постійно мешкає } \\
\text { в Солсбері, спіл- } \\
\text { кується з одухот- } \\
\text { вореним містом. } \\
\text { Дім, чай з пиро- } \\
\text { гом, затишок, } \\
\text { сад. Обмежена } \\
\text { рухомість - пора- } \\
\text { нене стегно. }\end{array}$ \\
\hline $\begin{array}{l}\text { Порушники } \\
\text { балансу }\end{array}$ & $\begin{array}{l}\text { Мерлін та його } \\
\text { поплічники. } \\
\text { Ритуал як насиль- } \\
\text { ство над землею } \\
\text { та їі духами. }\end{array}$ & $\begin{array}{l}\text { Родина Дімбер, } \\
\text { спадкові відьми, } \\
\text { заборона на чоло- } \\
\text { віків, поневолені } \\
\text { духи в реліквіях. }\end{array}$ \\
\hline
\end{tabular}

Діти, вільні від закріплених гендерних ролей та шаблонів. Відновлювачі балансу.

Родді (неприйняття шаблонів, одивнення як сприйняття); Грундо (“дивний” хлопчик, дислексик); Нік («жертва» з іншого світу, чужий) Поступове розуміння землі як живої особистості. Шлях через ландшафт із садами як точками усвідомлення

Ідея саду як концентричної реальності фантазії $\epsilon$ провідною для письменниці. В автобіографії вона пише про три сади, які обов'язково оточують будинок, та де народжується розповідь: «Перша ділянка - всипаний гравісм широкий двір, де відбувається пересічні Життя і Смерть <...>, місие, де все починається, коли я пишу книгу. Впорядкований сад, оточений чегляним парканом, - сад, куди ти заходии із вигаданими друзями, сад формальної фантазії, $<\ldots>$ місие, де твориться оповідка <...>, основна частина книги. Зачарований замкнений сад, оточений кам'яним муром, - изарина таємниці та краси $<$...>, серие всього оповідання. Тут живуть старі перекази й магія, щэо чарує життя. < ..> Жодна книга мені не добра без такого таємного серия. <...> Але й існувати без периих двох неможливо» (скорочений, за браком місця, переклад мій - Є.К.) [ 10, с. 391-392]. Таким чином, сад у фентезі Діани
Вінн Джонс несе особливе смислове навантаження. Якщо дивитися на сад у фентезі Джонс як на доместиковану ділянку ландшафту, слід усвідомлювати, що така локація поєднує первинну природну хаотичність 3 результатом діяльності доместикатора. Саду властива потенційна хаотичність, i, відповідно, потреба в доместикаторі. При цьому його простір чітко обмежований при обов'язковій наявності отвору для входу/виходу. Показово, що в романі «Вогонь та болиголов» [12] сад $\epsilon$ місцем переходу між реальністю та іншосвітом, вибору між now here (тут і зараз, профанною реальністю) та nowhere сакральною реальністю недосяжного.

Шлях героїв «Змови Мерліна» - Родді й Ніка пролягає через сади як поворотні точки пошуку та усвідомлення істини. Функція кожної точки буде розглянута окремо.

1. Таємний сад в долині р. Северн. «Сад в саду» $[15$, с. 68$]$, місце концентрації сили, сповнене чистих джерел. В перших рядках опису тричі повторюється прийменник inside, що підкреслює прихованість та внутрішнє розташування саду: «< ...> a garden inside a garden. There was a garden inside the old walls - a garden inside a garden-cupped inside its own small valley and as old and green as the hills». Письменниця підкреслює древність саду (old, ancient), його ізольованість (inside, cupped, most secret place), його тишу (It was a quiet place. quiet strength, hushed and holy). Це місце сповнене життєдайної сили води, що струменить із джерел та криниці: Above all, it was alive with water - та призначене для спокійного перебування (well with the garden). Істинний відвідувач мав запросити цей сад прийти до нього, з повагою та благоговінням. «Це - острів іншосвіту, сповнений сили». Діти (Родді та Грундо) стають свідками згвалтування цього саду учасниками змови Мерліна. Через порушення тиші, насильство та прагнення влади сила й чистота залишають сад, разом 3 цим уходить 3 нього Володарка Северна, згортаючи, немов тканину, ту чистоту, яка залишилася: «all the power and virtue and goodness that was left $\rangle[15, \mathrm{c}$. 309]. Після спаплюження сад засихає, життя змінюється гниллю: «I found a yellow-white ghostly layer of rottenness over everything» [15, c. 308]. Вода зникає, вона вже не біжить вільно. Домінує відчуття загибелі, знищення й поневолення. Функція цього місця усвідомлення сакрального центру та свідчення про порушення балансу. Таємний сад - відправна точка квесту Родді для підняття землі.

2. Неолітичне село. Древнє поселення, яке перетворилося на дикий сад, оточений кам'яними бри- 
лами. Зарості диких трав та кущів від горобини до вересу (перелік налічує 14 найменувань у невеличкому абзаці, кожна рослина згадується в легендах і народній медицині) живляться від водоспаду. Місце заховане від стороннього ока - воно «secret». Дикий сад, що утворився на місці колишнього неолітичного поселення, $є$ інверсійним прикладом зворотної доместикації, по суті, зміна ландшафту проводиться самою землею: там, де зникли люди, виникає таємний сад. Функція цісї точки квесту Родді - встановлення діалогу з землею (саме в цьому пошуку вона чує про необхідність «підняти землю») та отримання й символізація знань через рослини й пам'яті про поневолену скривджену відунку.

3. Сад родини Дімбер. Сад в садибі спадкових відьом, які практикують суто жіночу магію та зневажають чоловіків, розриваючи шлюб, щойно в ньому народжується дівчинка здатна продовжувати родинне ремесло. В домі Дімбер зберігаються сосуди з поневоленими духами місцини, які для відьом є джерелом сили. Земля в їх саду пересихає, рослинність дуже бідна, це «bare garden», з кошлатою травою та єдиним підстриженим деревцем (символ насильства проти природи). Родді усвідомлює, що за станом саду криється якесь викривлення: «Як дивно, подумала я. Я завжди гадала, щзо відьми розводять трави та взагалі навколо них все має бути оповите плідністю»[15, с. 289]. Функція цього місця - сигнал про зрушення балансу, небезпеку поневолення землі та ізоляції жіночого початку.

4. Сад Джерома Кірка, учасника змови Мерліна. Описується очима Ніка. Сад знаходиться неподалік від лісу, де перебуває Лорд Хранитель Островів, та пагорба, де спить Дракон. Попри близькість до місць сили, сад занедбаний та зловісний. В ньому ростуть понівечені фруктові дерева, що чіпляють відвідувачів гілками та шипами, плоди на хворих гілках бліді та червиві, заболочена місцина породжує бур'ян та кропиву [15, с. 373]. При цьому сам господар пишається своїм садом і варить сидр 3 гнилих плодів. Сад розкриває суть змовників хижацьке виснаження землі та неповага до іiі дарів, спроба брати, та нічого не давати у відповідь.

5. Сади мага Максвелла Гайда (Лондон) й чарівника Романова (між світами), які також описуються Ніком, виступають як індикатори стану землі та її господаря.

Таким чином, кожен сад усвідомлюється героями роману як свідчення, зумовлює динамічне одивнення та оновлення світосприйняття персо- нажів. Перехід від саду до саду переконує дітей в необхідності здійснити радикальний акт доместикації: «підняти землю» задля відновлення балансу сил на Островах.

Обряд підняття землі чинять одночасно два персонажі: Мерлін, який керується насильницькою волею та апелює до землі через криваву жертву, та Родді, яка звертається до землі за допомогою «квіткових файлів» давньої відунки та ретельно розпускає нитки магії, що зв'язувала землю. Дії Родді описуються через синоніми розплутування та образ спіралі: unbinding, unravel, unbound the vortex, you fed into it each of the other Great Spells. Вступаючи у діалог із землею, Родді йде від уяви до створення моделі переплутаних ниток («котяча колиска»), вербалізує свої дії, та підтримує ментальну роботу жестами, тобто відбувається ментальна, тілесна та емоційна взаємодія з ландшафтом. Зрештою, коли земля повністю звільнена від магії, що її зв'язувала, Родді бачить леді Володарку Северна, яка розстилає очищену землю, мов тканину, та впорядковує iii. Таким чином, доместикаційні дії Родді полягають у відторгненні шаблонного світосприйняття, свідченні про порушення балансу, отриманні й впорядкуванні знань, розплутуванні й змотуванні переплутаних ниток (апеляція до архетипу Пряхи) та звільнення поневолених сил землі. Звільнення землі передбачає добровільну відмову людини від угоди, знань та магії, укладання нової добровільної угоди та відновлення балансу.

\section{Висновки}

Динамічне одивнення в романі «Змова Мерліна» Діани Вінн Джонс, адресоване персонажам, а через них - читачеві, передбачає осмислення взаємодії людини (доместикатора) і ландшафту, засноване на презумпції первинної угоди між людиною $і$ землею, протидії насильницькому підкоренню, яке породжує хаос і дисбаланс, оновленню світогляду людини через розторгнення угоди та звільнення поневолених сил, укладанні нової - добровільної угоди. Процес динамічного одивнення відбувається через рух ландшафтом з точками сили в садах та історичних місцях (дракон - Уфінгтонський Білий Кінь, кузня Вейланда, Стоунхендж, Старий Сарум тощо). Наслідком динамічного одивнення $\epsilon$ відновлення балансу сил. Доместикація, яку в міфології здійснює культурний герой [1, с. 665], облаштовуючи світ, в романах Діани Вінн Джонс чиниться архетиповими фігурами Ткалі, Пряхи та Барда. Але, на відміну від традиційної міфології, культурний герой не підкоряє землю, а розуміє 
ii, виступаючи посередником між нею та людьми (племенем, народом). Його дії спрямовані на винайдення каналів спілкування із землею, символізації та номінації явищ, вони засновані на

\section{СПИСОК ВИКОРИСТАНИХ ДЖЕРЕЛ}

1. Мифология: Энциклопедия / [гл. ред. Мелетинский Е. М.] - М. : Большая Российская Энциклопедия. Дрофа, 2008. - 736 с.

2. Пропп В. Я. Исторические корни Волшебной сказки / Владимир Пропп. - М.:Лабиринт, 1998. - 361 с.

3. Пропп В. Я. Морфология волшебной сказки / Пропп В. Я. - М. : Лабиринт, 1998. - 512 с.

4. Рязанцева Т. М. Магія метафор : механізми взаємодії «Пісні» Джона Донна і «Мандрівного замку Хаула» Діани Вінн Джонс / Т.М. Рязанцева // Вісник Львівського університету. Серія іноземні мови. - Львів, 2016. - Вип. 24, ч. 2. - С. 64-69.

5. Тихомирова О.Священні дерева в альтернативній міфології Дж.Р.Р.Толкіна // Наукові праці: Науково-методичний журнал. - Т. 118. Вип. 105. Філологія. Літературознавство. - Миколаїв: Видво ЧДУ ім. Петра Могили. 2009. С. 76-81

6. Butler C. Enchanting Places: Readers and Pilgrimage in the Novels of Diana Wynne Jones [Електронний ресурс] / Catherine Butler // Strange Horizons. - 2014. - Режим доступу до ресурсу: http://strangehorizons.com/non-fiction/articles/ enchanting-places-readers-and-pilgrimage-in-thenovels-of-diana-wynne-jones/.

7. Butler C. Four British fantasists: place and culture in the children's fantasies of Penelope Lively, Alan Garner, Diana Wynne Jones, and Susan Cooper / Charles Butler., 2006. - 322 p.

8. Crowe E. The Wit and Wisdom in the Novels of Diana Wynne Jones / Crowe E. A. - Brigham Young University, 2005. - 77 p.

\section{REFERENCES}

1. Mifologiya: Entsiklopediya. gl. red. Meletinskiy E. M. [Mythology: Encyclopedia. Ed. Meletinskiy E. M.] M. : Bolshaya Rossiyskaya Entsiklopediya. Drofa. , 2008, 736 p. (in Russian).

2. Propp V. Ya. Istoricheskie korni Volshebnoy skazki [The historical roots of the Fairy Tale]. M.:Labirint, 1998, 361 p. (in Russian).

3. Propp V. Ya. Morfologiya volshebnoy skazki [Morphology of a fairy tale] M. : Labirint, 1998, 512 p. (in Russian).

4. Riazantseva T. M. Mahiia metafor : mekhanizmy vzaiemodii «Pisni» Dzhona Donna $i$ «Mandrivnoho zamku Khaula» Diany Vinn Dzhons [The Magic of Metaphors: The Mechanisms of the Interaction неантропоцентричному й екологічному мисленні. Дослідження прийомів символізації та вербалізації досвіду в романах Діани Вінн Джонс потребує продовження та поглиблення.

9. Hunt P. Landscapes and Journeys, Metaphors and Maps: The Distinctive Feature of English Fantasy / Peter Hunt. // Children's Literature Association Quarterly. - 1987. - №12.-p. 11.

10. Jones D. W. Birthing a Book / Diana Wynne Jones. // Horn Book Magazine. - №80. - C. 379-393.

11. Jones D. W. Cart and Cwidder/ Diana Wynne Jones. - New York: Greenwillow Books, 2001. - 240 p.

12. Jones D. W. Fire and Hemlock / Diana Wynne Jones. - New York : Greenwillow Books, 1985. - 239 p.

13. Jones D. W. Howl's Moving Castle / Diana Wynne Jones. - New York : Greenwillow Books, 2001.-336 p.

14. Jones D. W. House of Many Ways / Diana Wynne Jones. - New York : Greenwillow Books, 2009. - 432 p.

15. Jones D. W. The Merlin Conspiracy/ Diana Wynne Jones. - New York : Greenwillow Books, 2004. $-480 \mathrm{p}$.

16. Jones D. W. The Spellcoats / Diana Wynne Jones. - New York, : A Greenwillow Book, 2001. - 185 p.

17. Kaplan D. Diana Wynne Jones and the WorldShaping Power of Language / Kaplan Deborah. // Chrestomanci Castle, 2012. [Електронний pecypc] - Режим доступу до статті : http://suberic.net/ dwj/thesis.txt

18. Mendlesohn F. Diana Wynne Jones : children's literature and the fantastic tradition / Farah Mendlesohn. - N.Y., L. : Routledge, 2005. - 240 p.

19. Diana Wynne Jones: An Exciting and Exacting Wisdom / [T. Rosenberg, M. Hixon, S. Scapple та iн.]. - New York: Peter Lang, 2002. - 187 c.

of John Donne's "Songs" and Diana Wynn Jones's "Howl's Moving Castle"] in Visnyk Lvivskoho universytetu [Visnyk of the Lviv University]. Seriia inozemni movy [Series Foreign Languages]. Lviv, 2016, issue 24, part 2, P. 64-69. (in Ukrainian)

5. Tykhomyrova O. Sviashchenni dereva $v$ alternatyvnii mifolohii Dzh.R.R.Tolkina [Sacred trees in the alternative mythology of J.R.R. Tolkien] in Naukovi pratsi: Naukovo-metodychnyi zhurnal [Scientific works: Scientific and methodical journal] vol. 118. issue. 105. Filolohiia. Literaturoznavstvo [Philology. Literary Studies]. - Mykolaiv: Vyd-vo ChDU im. Petra Mohyly, 2009, P. 76-81. (in Ukrainian) 
6. Butler C. Enchanting Places: Readers and Pilgrimage in the Novels of Diana Wynne Jones [Електронний ресурс] / Catherine Butler // Strange Horizons. - 2014. - Режим доступу до ресурсу: $\mathrm{http}: / /$ strangehorizons.com/non-fiction/articles/ enchanting-places-readers-and-pilgrimage-in-thenovels-of-diana-wynne-jones/.

7. Butler C. Four British fantasists: place and culture in the children's fantasies of Penelope Lively, Alan Garner, Diana Wynne Jones, and Susan Cooper / Charles Butler., 2006. - 322 p.

8. Crowe E. The Wit and Wisdom in the Novels of Diana Wynne Jones / Crowe E. A. - Brigham Young University, 2005. - $77 \mathrm{p}$.

9. Hunt P. Landscapes and Journeys, Metaphors and Maps: The Distinctive Feature of English Fantasy / Peter Hunt. // Children's Literature Association Quarterly. - 1987. - №12.-p. 11.

10. Jones D. W. Birthing a Book / Diana Wynne Jones. // Horn Book Magazine. - №80. - C. 379-393.

11. Jones D. W. Cart and Cwidder/ Diana Wynne Jones. - New York : Greenwillow Books, 2001. - 240 p.
12. Jones D. W. Fire and Hemlock / Diana Wynne Jones. - New York: Greenwillow Books, 1985. -239 p.

13. Jones D. W. Howl's Moving Castle / Diana Wynne Jones. - New York : Greenwillow Books, 2001. $336 \mathrm{p}$.

14. Jones D. W. House of Many Ways / Diana Wynne Jones. - New York: Greenwillow Books, 2009. - 432 p.

15. Jones D. W. The Merlin Conspiracy / Diana Wynne Jones. - New York : Greenwillow Books, 2004. $-480 \mathrm{p}$.

16. Jones D. W. The Spellcoats / Diana Wynne Jones. - New York, : A Greenwillow Book, 2001. - 185 p.

17. Kaplan D. Diana Wynne Jones and the World-Shaping Power of Language / Kaplan Deborah. // Chrestomanci Castle, 2012. [Електронний ресурс] - Режим

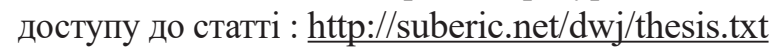

18. Mendlesohn F. Diana Wynne Jones : children's literature and the fantastic tradition / Farah Mendlesohn. - N.Y., L. : Routledge, 2005. -240 p.

19. Diana Wynne Jones: An Exciting and Exacting Wisdom / [T. Rosenberg, M. Hixon, S. Scapple та ін.]. - New York: Peter Lang, 2002. - 187 c.

\title{
DYNAMIC DEFAMILIARIZATION AS A WAY TO DOMESTICATE THE LANDSCAPE EMOTIONALLY IN DIANA WYNNE JONES' FANTASY NOVELS
}

\author{
Yevheniia Kanchura \\ https://orcid.org/0000-0003-1232-1920 \\ ivha89@gmail.com \\ Associate professor of the Theoretical and Applied Linguistics Department \\ "Zhytomyr Polytechnic" State University
}

\begin{abstract}
In the works by D. W. Jones, British landscape is not just a geographical location but presents the dynamic potential of a separate place which is manifested in fantasy-narrative. The characters of her novels, like the cultural heroes of cosmogonic myths, organize the space, restoring the disturbed balance of forces and establishing the harmony of the spiritual and the material. The paper examines the literary tools of fantasy allowing to model the transformation of the landscape as carried out through rethinking and verbal reformulation of the landscape and embodied in physical action (weaving, untangling the threads, playing a musical instrument, etc.). Verbalization of the relationship between a man and the land involves an agreement between the parties based on the recognition of the freedom of will. The process of domestication is regarded as the transformation of the unknown, chaotic world into space by nomination, incorporation into the history of the people and the defining of the sacred core. The writer resorts to two types of defamiliarization: the one which is typical for the fantasy meta-genre, addressed to the reader, and a kind of dynamic defamiliarization as a means of domestication, the driving vehicle of the plot, embodied in the system of characters and geographical locations. The main heroes in The Merlin Conspiracy (2003) travel through the landscape of alternative England, where the turning points are the gardens, the parts of landscape representing the concentric reality of fantasy, domesticated fragments of the landscape. The dynamic defamiliarization determines the understanding of the interaction of man (domesticator) and the landscape. The functions of a postmodern cultural hero combine archetypal actions with new non-anthropocentric and eco-feminist thinking.
\end{abstract}

Key words: postmodern fantasy; domestication; defamiliarization; cultural hero; Diana Wynn Jones; The Merlin Conspiracy. 